International Journal of Engineering \& Technology, $7(2.29)(2018) 491-493$
International Journal of Engineering \& Technology
SPC
Website: www.sciencepubco.com/index.php/IJET
Research paper

\title{
Study Analysis of Knowledge Mother and Environmental Conditions of Occurrence of Acute Respiratory Infections in Children
}

\author{
Yarmaliza Dan Marniati ${ }^{1 *}$ \\ ${ }^{1}$ Faculty Of Public Health, Universitas Teuku Umar, Aceh Barat, Indonesia \\ *Corresponding Author E-Mail: Yarmaliza
}

\begin{abstract}
Acute Respiratory Infections still menjdi major health problem in the world. According to the World Health Organization estimates that the incidence of acute respiratory infection in developing countries with under-five mortality above 40 per 1,000 live births is $15 \%-20 \%$ per year in the toddler age group. About 13 million children under five in the world die each year and most of these deaths are in developing countries. Panga in the health center of the top 10 diseases, acute respiratory infections ranked first in the amount of $65 \%$ by the sheer number of infants 158. The aim of research to influence knowledge megetahui Mother and environmental conditions on the incidence of acute respiratory infections in Toddlers in Panga sub-district Puskesmas Panga Aceh Jaya 2014. this study is a descriptive analytic with cross sectional approach. The sampling technique using random sampling techniques, selected at random from each member of the population, an analysis of the data in this study using univariate and bivariate. The survey results revealed that mother's knowledge and environmental conditions affect the incidence of ARI in Toddlers $(\mathrm{P}<0.05)$.
\end{abstract}

Keywords: Acute respiratory infections; children; developing countries

\section{Introduction}

Acute Respiratory Infections (ARI) still menjdi major health problem in the world. According to the World Health Organization estimates that the incidence of acute respiratory infection (ARI) in developing countries with under-five mortality above 40 per 1,000 live births is $15 \%-20 \%$ per year in the toddler age group. About 13 million children under five in the world die each year and most of these deaths are in developing countries (WHO, 2011). In developing countries, including Indonesia from year to year, Acute Respiratory Infections has always ranked top causes of infant kematia (0 -11 months) and toddlers (1-5 years) at 10\% - $20 \%$. Acute Respiratory Infections is caused by a virus or bacteria. The disease begins with a hot accompanied by one or more symptoms such as sore throat or painful swallowing, runny nose, dry cough or phlegm. The incidence and prevalence of Indonesia in 2013 were $1.8 \%$ and $4.5 \%$. Five provinces with the highest Acute Respiratory Infections is the East Nusa Tenggara (41.7\%), Papua $(31.1 \%)$, Aceh $(30.0 \%)$ West Nusa Tenggara $(28.3 \%)$ and East Java (28.3\%).Acute Respiratory Infections is a leading cause of patient visits to health facilities. From the figures in Indonesia in the hospital can be that $40 \%-70 \%$ of children treated at the hospital was with ARI and 15\% - 30\% visit Acute Respiratory Infections patients assigned to outpatient treatment and hospitalization (Ministry of Health, 2012)

In 2013 provision Aceh was ranked the third highest three cases of Acute Respiratory Infections, with incidence prevalence among children under five by $1.8 \%$ and $5.4 \%$. Based on data from the Indonesian Demographic Health Survey (IDHS), sekitas 35.4\% of children suffer from cough in the last two weeks and $39.1 \%$ had a fever. Estimates IDHS child pneumonia approximately $40 \%-43 \%$. Based on the Indonesian Demographic Health Survey (IDHS) Aceh province in 2013 showed that $88.2 \%$ children seek treatment at a health facility with symptoms of acute respiratory infection (Aceh Provincial Health Office, 2013).

In Aceh Jaya district Acute Respiratory Infections cases in 2014 by $65 \%$ in young children, while according to the secondary data Panga Aceh Jaya District Health Center since January until August 2014 was recorded at 36 under five suffering from pneumonia cough is not experiencing severe pneumonia while there were 19 cases. There are many factors that influence the incidence of ARI peyakit either directly or indirectly. According to the Department of Health (2002) mentions that the risk factors that cause acute respiratory infection in infants is socio-economic (income, housing, parental education, nutritional status, level of knowledge of maternal and environmental factors). The incidence of ARI in Aceh Jaya district at the end of 2013 the number of people with less than a total of 156 toddlers, while at the health center of the 10 major Panga existing disease namely ISPA was ranked first by $65 \%$ by the sheer number of 158 children under five.

The Research showed that $65.9 \%$ result of knowledge of mothers about ARI in infants is still very low and also the results of research conducted by (1) the attitude of a mother against respiratory diseases in districts Sindereng Rappang in getting that knowledge and mother attitude about the respiratory disease is still very low with most mothers do not understand about ISPA and how to cope with children suffering from Acute Respiratory Infections. 


\section{Research Methodology}

Descriptive analytic research with cross sectional approach, the aim to see the effect of the mother's knowledge and environmental conditions on the incidence of acute respiratory infections (ARI) in children under five. This research has been conducted in Puskesmas Panga Panga District of Aceh Jaya and in July to August 2014. The population in this study are all mothers who have children with the disease ISPA taken from July to August which amounted to 141 infants in sub-district Puskesmas Panga Aceh Jaya in 2014. How sampling using random sampling, the sample was randomly selected and each member of the population has a chance to be sampled (2). Criteria for the sample in this study is the mother had a toddler with penakit ISPA, babies under 6 months of age and health centers located in the region of Aceh Jaya Panga.

Result

Table 1: Distribution of respondents by Knowledge in Puskesmas Panga District of Aceh Jaya

\begin{tabular}{|c|c|c|c|}
\hline No & Knowledge & Frequency & \% \\
\hline 1 & Good & 34 & 58,6 \\
\hline 2 & Bad & 24 & 41,4 \\
\hline Total & & 58 & 100 \\
\hline
\end{tabular}

\subsection{Environment}

Table 2: Distribution of respondents by the Environment on the territory Panga Puskesmas District of Aceh Jaya

\begin{tabular}{|c|c|c|c|}
\hline No & Environmental & Frekuensi & \% \\
\hline 1 & Good & 25 & 43,1 \\
\hline 2 & Bad & 33 & 56,9 \\
\hline Total & & 58 & 100 \\
\hline
\end{tabular}

\subsection{ISPA (Acute Respiratory Infections)}

Table 3: Distribution of respondents by respiratory disease that occurs in infants in Puskesmas Panga Panga District of Aceh Jaya

\begin{tabular}{|l|c|l|l|}
\hline No & Acute Respiratory Infections & Frekuensi & \% \\
\hline 1 & Heavy & 19 & 32,8 \\
\hline 2 & Light & 39 & 67,2 \\
\hline Total & & 58 & 100 \\
\hline
\end{tabular}

\subsection{Bivariate analysis}

Table 4: Distribution of respondents by knowledge of mother in Puskesmas Panga Panga District of Aceh Jaya

\begin{tabular}{|l|l|l|l|l|l|l|l|}
\hline \multirow{2}{*}{ No } & \multirow{2}{*}{ Knowledge } & \multicolumn{3}{|c|}{ Acute Respiratory Infections } & \multirow{2}{*}{ Heavy } & \multirow{2}{*}{$\%$} \\
\cline { 3 - 6 } & & N & \% & n & \% & & \\
\hline & Good & 8 & 23,5 & 26 & 76,5 & 34 & 100 \\
\hline \multicolumn{2}{|l|}{ Bad } & 11 & 45,8 & 13 & 54,2 & 24 & 100 \\
\hline \multicolumn{2}{|l|}{ Total } & 19 & - & 39 & - & 58 & - \\
\hline
\end{tabular}

Table 5: Distribution of respondents by the Environment in Puskesmas Panga Panga District of Aceh Jaya

\begin{tabular}{|c|c|c|c|c|c|c|c|}
\hline \multirow{3}{*}{ No } & \multirow{3}{*}{ Envirzonment } & \multicolumn{4}{|c|}{$\begin{array}{c}\text { Acute Respiratory Infec- } \\
\text { tions }\end{array}$} & \multirow{3}{*}{ Total } & \multirow{3}{*}{$\%$} \\
\hline & & \multicolumn{2}{|c|}{ Heavy } & \multicolumn{2}{|c|}{ Light } & & \\
\hline & & $\mathbf{N}$ & $\%$ & $\mathbf{n}$ & $\%$ & & \\
\hline & Good & 7 & 28,0 & 18 & 72,0 & 25 & 100 \\
\hline & $\mathrm{Bad}$ & 12 & 36,4 & 11 & 33,4 & 33 & 100 \\
\hline \multicolumn{2}{|c|}{ Total } & 19 & - & 39 & - & 58 & - \\
\hline
\end{tabular}

\section{Discussion}

\subsection{Knowledge with Acute Respiratory Infections dis- ease}

Knowledge is not necessarily a good mother is not infected babies' respiratory disease. This is evident from the mothers who were around Puskesmas Panga District of Panga Aceh Jaya who on average have a good knowledge but babies still experiencing respiratory disease, but the Acute Respiratory Infections are exposed to a mild Acute Respiratory Infections, it is different with the mother who do not have knowledge of the more vulnerable children affected by respiratory diseases (3).

The results support the research (4), states that mothers with little education and less counseling by health workers will likely not know how to give good care and the right medicine to drink and was on his Acute Respiratory Infections. This is supported by the opinion (5), which states that one of the factors influencing knowledge to health is the educational level. People who have a good education has the ability to absorb and understand the knowledge he received. So, the better one's education, the more easy to absorb and understand the knowledge received (6).

According to (7) states that, knowledge of a mother affects behavior of mothers in the prevention of Acute Respiratory Infections do like keeping the child remains in a clean state, the mother did cleaning the house such as sweeping the floor, cleaning the dust in the house, regularly changing bed linen mattresses and gloves pillows regularly, open windows and air vents for air circulation remains smooth and prohibit family members who smoke to not smoke. Action in preventing ARI respondents are either affect infant health.

One example of the mother's behavior is less support in the prevention of Acute Respiratory Infections is the mother never opened the window of the house in the morning and during the day so the sun cannot get into the house. Mom did the cleanliness of the floor as mopping floors or cleaning tables and other furniture from dust with a rag. Respondents still do not understand that with a healthy behavior such as opening the window ventilation, clean up the dust on the table or chair is a good action in order to prevent the occurrence of acute respiratory infection in infants.

This is reinforced by the opinions (8), that the low level of knowledge and skills of the family, especially the mother became one of the triggers of acute respiratory infection in infants. Most of the families who have toddlers at home Acute Respiratory Infections is the mother who does not know how to prevent respiratory infection. According to (9) that the higher a person's knowledge would Acute Respiratory Infections, the incidence of Acute Respiratory Infections happens to be lower, and vice versa if someone with a good knowledge low against respiratory infections, the incidence of Acute Respiratory Infections that occurred will be higher received (10).

In line with the research that has been done maternal characteristics that affect the picture with Acute Respiratory Infections in infants with a good knowledge is 34 respondents or $58.62 \%$, while that is not good only 24 respondents or 41.38 . Thus, the mother's knowledge is instrumental in anticipating outbreaks of respiratory disease. This shows mothers who have no knowledge more vulnerable infants exposed to Acute Respiratory Infections (11).

If the researchers attribute to the research conducted by Ariyanto of the Faculty of Public Health, University of Lampung with the title of the study the factors that influence the occurrence of acute respiratory infection in infants in Puskesmas Batang East Lampung, the results showed that the factor of maternal knowledge is affecting outbreaks of respiratory disease in infants result by 82 , $3 \%$ children infected with respiratory disease with the lowest maternal education category.

Knowledge is the result of the idea and occurred after the sensing of the particular object. Sensing occurs through the senses of the human senses of sight, hearing, offers taste, and touch. Most human knowledge is obtained through the eyes and ears. Cognitive knowledge or an act of a person (over behavior). (12).

\subsection{Environment with ISPA disease}

A good environment will certainly affect the susceptibility of the disease one of which is a respiratory infection. This is evident from the mothers who were around Puskesmas Panga Panga District of Aceh Jaya district on average has a good environment but the toddler was also experiencing respiratory disease, but the 
Acute Respiratory Infections affected by a mild Acute Respiratory Infections.

According to (13) Transmission of respiratory disease can occur through the air is polluted, the germs enter the body through breathing, therefore the respiratory diseases are categorized Water Borne Disease. Airborne transmission means is means of transmission that occurs without contact with the patient or with contaminated objects (14). Most airborne transmission can also be transmitted by direct contact, but not rare disease transmission is largely due to suck in air that contains elements of the cause or the causative organism (15).

The results also agree with (16), that there is a relationship between environmental factors with the occurrence of respiratory infections, particularly the home environment with a density in the rooms especially toddlers who are not in accordance with the standards will increase the room temperature caused by expenditure of body heat that will increase the humidity due the moisture from breathing. Thus, the more the number of occupants of the room, the faster the air bed room experience gas or bacterial contamination (17). With the number of inhabitants, the indoor oxygen levels decrease and followed by increased $\mathrm{CO} 2$ room University of North Sumatra and the impact of increased $\mathrm{CO} 2$ room is the reduction of indoor air quality (18).

In line with the research that has been made known that mothers who stay at The environment is nice to have a toddler Acute Respiratory Infections weigh as much as 7 toddler or $28 \%$, and mild Acute Respiratory Infections as many as 18 infants, or $72 \%$, while mothers who live in the neighborhood is not good to have a toddler Acute Respiratory Infections weigh as much as 12 toddlers or $36.4 \%$ and mild Acute Respiratory Infections as 11balita or $33.34 \%$, this shows the mother who stays at a good environment more vulnerable infants exposed to Acute Respiratory Infections (19).

If the researchers attribute to the research conducted by Ariyanto of the Faculty of Public Health, University of Lampung with the title of the study the factors that influence the occurrence of acute respiratory infection in infants in Puskesmas Batang East Lampung, the results showed that environmental factors are very influential on contracted respiratory disease in infants result show that of the environment is greater contracting Acute Respiratory Infections compare good environment that is equal to $91 \%$ (20).

According (12) Environment is everything that exists around the individual, both the physical environment, biological, and social. Environmental influence on the process of entry into the knowledge of individuals who are in the neighborhood (21). This is due to the interaction of reciprocal or not will respond as knowledge by every individual.

\section{Conclusion}

There is the influence of the mother's knowledge and environmental conditions with the incidence of acute respiratory infections in children under five. It is expected to do further research on other factors which may cause the occurrence of Acute Respiratory Infections in infants.

\section{References}

[1] Bachtiar I, editor Promoting recruitment of scleractinian corals using artificial substrate in the Gili Indah, Lombok Barat, Indonesia Proceedings of the Ninth International Coral Reef Symposium, Bali, 23-27 October 2000; 2002.

[2] Notoatmodjo S. Metodologi Penelitian Kesehatan Jakarta: Rineka Cipta..(2007). Promosi kesehatan teori dan ilmu perilaku Jakarta: Rineka Cipta. 2002.

[3] Wilson D, Hockenberry J. Clinical Manual Of Pediatric Nursing. USA: Cv Mosby-Year Book. Inc; 2008.

[4] Kusno I, Ismail D, Kushadiwijaya H. Tatalaksana oleh Petugas Kesehatan dan Faktor Risiko Terjadinya Kegagalan Perawatan di Rumah terhadap Penderita Pnemonia Balita. Berita kedokteran masyarakat. 2003;19(2003).
[5] Parera Giro S. Sehat Suatu Pilihan Bebas. Diakses dari: http//www. indomedia. com; 2004.

[6] Murharyati A. Hubungan Antara Tingkat Pengetahuan dan Sikap Ibu dengan Praktik Cara Perawatan Balita yang Menderita ISPA Nonpneumonia di Wilayah Kerja Puskesmas Mojolaban I Kabupaten Sukoharjo. Jurnal KESMADASKA. 2010;1(1).

[7] Mishra V, Smith KR, Retherford RD. Effects of cooking smoke and environmental tobacco smoke on acute respiratory infections in young Indian children. Population and Environment. 2005;26(5):375-96.

[8] Arikunto S. Research Procedure A Practical Approach. Jakarta: PT Rineka Reserved. 2010.

[9] Montanari G, Ceschin F, Masotti S, Bravi F, Chinea B, Quartarone G. Observational study on the performance of the Narhinel method (nasal aspirator and physiological saline solution) versus physiological saline solution in the prevention of recurrences of viral rhinitis and associated complications of the upper respiratory tract infections (URTI), with a special focus on acute rhinosinusitis and acute otitis of the middle ear. Minerva pediatrica. 2010;62(1):916, 7-21.

[10] Broor S, Pandey R, Ghosh M, Maitreyi R, Lodha R, Singhal T, et al. Risk factors for severe acute lower respiratory tract infection in under-five children. Indian pediatrics. 2001;38(12):1361-9.

[11]1Smeltzer SC, Bare BG. Buku ajar keperawatan medikal bedah. Jakarta: EGC. 2002;1223:21.

[12] Notoatmodjo S. Promosi kesehatan dan ilmu perilaku. Jakarta: Rineka Cipta. 2007;20

[13]Botelho C, Correia AL, Silva AMCd, Macedo AG, Silva COS. Environmental factors and hospitalization of under-five children with acute respiratory infection. Cadernos de saude publica. 2003;19(6):1771-80.

[14]Bezerra PG, Britto MC, Correia JB, Maria do Carmo M, Fonceca $\mathrm{AM}$, Rose K, et al. Viral and atypical bacterial detection in acute respiratory infection in children under five years. PloS one. 2011;6(4):e18928.

[15] Yusup NA, Sulistyorini L. Hubungan sanitasi rumah secara fisik dengan kejadian ISPA pada balita. Jurnal kesehatan lingkungan. 2005;1(2):110-9.

[16]Hemalatha R, Swetha GK, Seshacharyulu M, Radhakrishna K. Respiratory syncitial virus in children with acute respiratory infections. The Indian Journal of Pediatrics. 2010;77(7):755-8.

[17]17. Oktaviani D, Fajar NA, Purba IG. Hubungan Kondisi Fisik Rumah dan Perilaku Keluarga Terhadap Kejadian ISPA pada Balita di Kelurahan Cambai Kota Prabumulih Tahun 2010. Jurnal Pembangunan Manusia. 2010;4(3):239-53.

[18] Wayse V, Yousafzai A, Mogale K, Filteau S. Association of subclinical vitamin D deficiency with severe acute lower respiratory infection in Indian children under 5 y. European journal of clinical nutrition. 2004;58(4):563.

[19] Watania MJ. Respirologi Anak, edisi pertama. Jakarta: Ikatan Dokter Anak Indonesia; 2008.

[20]Hood A, Mukty A. Dasar-dasar Ilmu Penyakit Paru. Airlangga University Press Surabaya. 2006.

[21]Brown KH. Diarrhea and malnutrition. The Journal of nutrition. 2003;133(1):328S-32S 